\title{
OLD WINE IN NEW BOTTLES: EXPLORING PRAGMATISM AS A PHILOSOPHICAL FRAMEWORK FOR THE DISCIPLINE OF COACHING
}

\author{
TATIANA BACHKIROVA \\ SIMON BORRINGTON \\ Oxford Brookes University, UK
}

\begin{abstract}
The practice and industry of organizational coaching are now well-established, but how it is understood theoretically continues to lag behind. Here, we analyze possible reasons for this state of affairs and argue that the development of coaching as an academic discipline will benefit from adopting philosophical pragmatism as an overarching theoretical framework. This move will enable coaching academics to utilize the contributions to knowledge that different paradigms generate. Positioning pragmatism as a theory of action, we argue that organizational coaching is by default a pragmatic enterprise and provide three examples of the considerable benefits to be gained by conceptualizing it this way: (1) Drawing from the pragmatists' ideas, particularly those of John Dewey, we demonstrate how the theoretical understanding of organizational coaching can be enhanced by considering its nature as a joint inquiry; (2) Pragmatism suggests development as an ultimate purpose for organizational coaching, which also helps to resolve fundamental conceptual debates; and (3) In light of the complexity and diversity involved in the way that organizational coaching is practiced, pragmatism offers coaches a useful framework for developing the flexibility required for navigating the multiplicity of influences on their practice.
\end{abstract}

There is no doubt that coaching practice in an organizational context is now well-established (CIPD, 2015; ICF, 2016; Grant, Passmore, Cavanagh, \& Parker, 2010; de Haan \& Duckworth, 2013; Theeboom, Beersma, \& van Vianen, 2013; Athanasopoulou \& Dopson, 2015; Ellinger, Hamlin \& Beattie, 2017), and can be recognized as "a mainstream activity in organizations worldwide" (Grant, 2013: 15). It is an occupation for a substantial number of professional coaches (ICF, 2016); it has become an additional fully recognized role for internal coaches (Ridler Report, 2013); and it is a strongly encouraged activity for managers in supporting employees (Ellinger, Beattie, \& Hamlin, 2014). Both the numbers of postgraduate courses in coaching in the UK and the number of institutions offering continuing education in coaching in the US have reached triple figures (Fillery-Travis \& Collins, 2017) to meet this demand.

We are grateful to our colleagues, Dr. Elaine Cox, Dr. Peter Jackson, Dr. Judie Gannon, Dr. Ioanna Iordanow, and Dr. Adrian Myers for their comments on the early draft of this paper and for useful discussions as it was developing. We also owe our gratitude to the editor and anonymous reviewers for constructive criticism that helped to take our ideas to the next level.
However, we argue that currently it is an industry without a discipline, where a "discipline" is a branch of knowledge that is sufficiently developed to be recognized as such by learned societies (Serenko \& Bontis, 2013).

To grow into a recognized discipline, which in the case of organizational coaching would be a "softapplied" discipline, for example, along with management or education (Becher, 1994; Serenko \& Bontis, 2013), coaching scholars should aim to demonstrate the fulfillment of at least two functions: The first concerns theoretical developments that advance conceptual understanding of the phenomena of organizational coaching and the body of knowledge that acts as its epistemic foundation, which can be utilized to inform other disciplines. The second function is about contributions made to improvements in the state of practice and, by extension, quality of life (Serenko \& Bontis, 2013: 137-138).

Several established coaching scholars argue that there is some evidence of progress being made in relation to both of these functions in the forming of coaching as a discipline (Fillery-Travis \& Collins, 2017; Grant, 2011; Stern \& Stout Rostron, 2013; de Haan, Bertie, Day, \& Sills, 2010). However, others 
show concern that the theoretical understanding of coaching practice, particularly essential for the fulfillment of the first function, is thus far less than satisfactory (Boyatzis, Smith, \& Van Oosten, 2015; Ellinger, Hamlin, \& Beattie, 2008; Western, 2012; Cox, Bachkirova, \& Clutterbuck, 2014a; Athanasopoulou \& Dopson, 2015; Myers, 2017). Although the literature on coaching practice keeps growing and offers many models and definitions of coaching, several of those models are opinion-based marketing devices primarily developed by practitioners to promote their specific approaches to coaching, which are rarely supported by empirical research or justified by conceptual analysis (Jackson, 2004).

We suggest that what seems to be lacking for the development of organizational coaching as a discipline is serious conceptual work that problematizes coaching practice in organizations, builds on relevant ideas and concepts from other fields, and offers theoretical propositions that are uniquely relevant to organizational coaching (Western, 2012; Cavanagh \& Lane, 2012; Bachkirova, 2017). We believe that this conceptual work is needed to provide new meaningful propositions and questions to test and explore beyond the mere asking of "whether coaching works or not" in research projects. This is important because this new type of research, in turn, will enhance our understanding of coaching practice and produce new theories unique to this discipline. We further argue that a strong theoretical understanding of coaching practice in organizations is essential for establishing the reputation of coaching as a discipline and increasing its potential contribution to wider knowledge. This could lead to coaching becoming a "reference discipline" which, as described by Serenko and Bontis (2013), is a discipline that provides theoretical, conceptual, and methodological contributions to other scientific disciplines.

That said, theoretical development of a new discipline alongside research projects and evidencebuilding requires at least two further conditions: good use of knowledge developed in other reference disciplines and effective dialogue between diverse contributors to knowledge. We argue here that philosophical pragmatism offers a unique contribution for the organizational coaching discipline in both of these regards.

The first condition implies informed engagement with the elements of practice, identified as definitions, domains, relationships, and predictive claims (Wacker, 1998), as well as consideration of these in the context of wider theoretical knowledge provided by other relevant disciplines. Theory-building in coaching should, therefore, benefit from the deliberation of insights gained into essential concepts that are concerned with human nature, learning, change, and development that have been the focus of attention in such "reference disciplines" as philosophy, psychology, psychotherapy, anthropology, sociology, and so forth (Cox, et al., 2014a). We believe that philosophical pragmatism can provide a sound framework for establishing essential elements of organizational coaching and inform on-going, unresolved issues and debates found in coaching literature. We include examples of how pragmatism can inform our theoretical understanding of coaching later below.

Theory building also inevitably implies an intention to engage with the question of what is considered credible knowledge (Bem \& de Jong, 2013); however, scholars working on the development of coaching as a discipline come from multiple theoretical backgrounds and fields of knowledge. As a consequence, it could be argued that the scholarship of organizational coaching "speaks different languages," depending on the intellectual origins of the commentators, and subsequently, uses different criteria of quality when judging research, publications, and coaching programs (Western, 2012; Cox et al., 2014a; Athanasopoulou \& Dopson, 2015). This variation in frameworks for assessment and analysis can also have a significant bearing on how professional practice should be conceptualized (Fishman, 1999; Peterson, 1991). For example, from what could be identified as a typical modernist worldview, the process of professional practice looks like a step-bystep approach that starts from laws discovered in core science, which are then modified in applied research, translated into a method, and finally delivered by professionals as an intervention to clients (Peterson, 1991). However, for those who take a more systemic view, actual practice has very little resemblance to this model (Stacey, 2003, 2012; Jones \& Corner, 2012; Cavanagh \& Lane, 2012; Cox et al., 2014a). According to this perspective, the interaction between clients and practitioners is based on subjective experience, as well as constant feedback and adjustments being made in line with these experiences: Beliefs, expectations, and mutual sensemaking are interactive, and local contexts and the wider environment become entangled, resulting in understanding the process as a much more complex dynamic (Alvesson, 2001).

A dialogue on the evaluation and application of knowledge from such different positions proves to be 
difficult (Western, 2012; Garvey, 2017; Bachkirova, 2017). We argue that this epistemic division has left the two sides talking past each other, resulting in barriers to the constructive dialogue necessary for the practical and theoretical needs of coaching being erected. We argue that pragmatism can be seen as a philosophical framework that enables and encourages such dialogue to take place in the development of coaching as a discipline (Fishman, 1999; Pihlstrom, 2015; Rumens \& Kelemen, 2016).

Moreover, it is our strongly held belief that pragmatism already underpins coaching as a practice, and recognition of this will benefit scholars and practitioners of organizational coaching. For example, reflexive recognition of the pragmatic attitude inherent in organizational coaching could help practitioners and students develop a more coherent rationale for their roles and models of practice, while being aware of the complexity involved in this task and the significant diversity of coaching approaches and styles available. Pragmatism can also further support coaching pedagogy in the design of coherent teaching programs with well-aligned theory and practice and provide an overarching framework for students to engage in debates about controversial concepts and ideas of organizational coaching in a progressively integrative way. The challenges to coaching educators regarding different philosophies of practice have been recently discussed, and call for deeper understanding of what philosophical pragmatism can offer (e.g., Bachkirova, Jackson, Gannon, Iordanou, \& Myers, 2017b; Lane, 2017).

We aim here at the academic coaching community, students and practitioners of organizational coaching. We are using "organizational coaching" in the same way as "workplace coaching" to specify coaching that involves a third-party sponsor (Bozer \& Jones, 2018). The intention to explore the concerns of the educators and students of coaching is one of the reasons for our focus on organizational coaching rather than, for example, the more elite and lucrative practice of executive coaching. It would be counterproductive for the educators of coaching to not pay attention to the many levels and variations in coaching assignments that their students are likely to experience early in their practice and throughout their coaching careers. Although we recognize the relevance of our argument to different modalities of coaching in organizations such as team coaching, we will restrict ourselves to the original one-to-one modality.

To be clear about our scope here, we also need to clarify our intention concerning our application of pragmatism. Although pragmatism as a philosophy of science (Bem \& de Jong, 2013; Martela, 2015a) would be a position of our choice for coaching research, here we focus on its role in the conceptualization of coaching practice in organizations and the recognition of knowledge in establishing organizational coaching as a discipline. The case for pragmatism in organizational research in comparison to alternative positions has recently been persuasively made by Martela (2015a), which we believe is also highly relevant to coaching research.

\section{THEORETICAL ISSUES IN THE LITERATURE ON ORGANIZATIONAL COACHING}

The insufficient progress so far in terms of a theoretical understanding of coaching practice has been identified by many authors (Boyatzis, Smith, \& Van Oosten, 2015; Garvey, Stokes, \& Megginson, 2014; Western, 2012; Cox et al., 2014a; Athanasopoulou \& Dopson, 2015; Bachkirova, 2017; Myers, 2017). According to Western (2012), for example, this lack stems from underestimating the importance of theories in a practitioner-driven field; the challenge of integrating diverse bodies of knowledge influencing this discipline; and the prevalence of a "scientific" attitude that equates development of theory with a search for simple causal links between measurable aspects of practice. This does not mean that organizational coaches work in "a theoretical vacuum" (Western, 2012: 224). It is inevitable that they hold theories that are explicitly or implicitly applied, but these theories could be self-created or uncritically assimilated from various sources, and thus, potentially problematic and not fit for the purpose (Jackson, 2004; Western, 2012). Coaching research alone, although on the rise (Grant, 2011), cannot solve this problem. Gathering knowledge needs a further step, which connects these findings together, explains relationships between underlying processes, and offers new hypotheses for testing. However, this conceptual work and theorizing to produce explanatory knowledge of coaching in organizations is still at a rudimentary stage.

Theoretical understanding of organizational coaching inevitably involves attempts to define this practice. The attempts made in the literature of both academics and practitioners show that coaching can be defined in many different ways (see, e.g., Bachkirova, Spence, \& Drake, 2017a). This is not surprising considering the significant diversity of coaching styles, applications, and the outcomes intended (Western, 2012; Myers, 2017). The plethora of terms (such as 
leadership coaching, executive coaching, business coaching), that are used without sufficient differentiation of one from another, does not help in setting out what coaching can offer for organizations (e.g., Korotov, 2017).

Here, we are using the generic term, organizational coaching, rather than trying to reduce the complexity of this situation by aligning with one type of coaching as outlined above to address the situation as it presents itself. The reality of the use of coaching in organizations, in both the public and private sectors, suggests that coaching is provided not only for executives or leaders (however these are identified), but also for various employees to develop new skills, and improve performance and overall capacity in various ways that organizations can benefit from (CIPD, 2015; Ridler Report, 2013). We certainly support this wider use of coaching in organizations, as it moves further away from the notions of coaching as an "elite perk" only available to a high-level echelon (Wasylyshyn, 2004). We believe that it is precisely the multiplicity of coaching approaches and applications covered by the term organizational coaching that helps this practice grow as it becomes better able to respond to the diverse needs of organizations.

We also argue that educators and students of coaching in organizations benefit from embracing the complexity of coaching practices, models, and applications. To demonstrate the variety of coaching in organizations, we describe several dimensions of diversity in coaching approaches that have been recognized in recent coaching literature (Table 1).

Our remit here is not to expand on each approach in this table, but to demonstrate that the field of coaching in organizations is in a state of expansion rather than consolidation. For example, the number of theoretical orientations (Dimension 1) applicable to organizational coaching has grown from the earlier to the later

TABLE 1

Dimensions of Diversity of Approaches in Organizational Coaching

\begin{tabular}{ll} 
No. Dimensions of Diversity in Organizational Coaching \\
\hline 1 & $\begin{array}{l}\text { Theoretical orientations of the coach, based on } \\
\text { different philosophies of individual change and } \\
\text { manifested in different ways of working with goals, } \\
\text { processes, relationships, and instruments of } \\
\text { coaching in organizations }\end{array}$
\end{tabular}

The depth of capacity-building requested by the client and/or presented as an area of expertise by the coach

The degree of focus on the individual or organizational needs

The depth of reflexivity involved in the process

5

Response to the needs of particular client groups in organizations

6

Emphasis on a specific element of coaching engagement considered most important by the coach

7
Discourse-based role variations of the coach in organizations
Approaches and Types of Coaching in Organizations

Solution-focused coaching (Cavanagh \& Grant, 2014); Gestalt coaching (Bluckert, 2014); Existential coaching (Spinelli, 2014), and many more, e.g., see 13 theoretical traditions in the Complete Handbook of Coaching (Cox, Bachkirova, \& Clutterbuck, 2014b).

From skills coaching (Tschannen-Moran, 2014) to performance coaching (Rogers, 2012; Wilson, 2007) to developmental coaching (Berger, 2012; Bachkirova, 2011) to transformational coaching (Hawkins \& Smith, 2013).

From strongly client-centered (Joseph, 2014) to organization-centered or wider system-centered, e.g., systemic coaching (Whittington, 2016).

From closely goal-focused following simple algorithms, such as GROW (van Nieuwerburgh, 2014), to deeply reflexive dialog, e.g., in line with co-constructed coaching advocated by Kempster \& Iszatt-White (2012) or conversation with a "criticalfriend" (Fillery-Travis \& Lane, 2006).

Talent management coaching (Bond \& Naughton, 2011); coaching for expatriates (Salomaa, 2015); coaching for employees with disabilities (Kavanagh, 2015); maternity coaching (Filsinger-Mohun, 2011), etc.

Resilience coaching (Lawton-Smith, 2017); narrative coaching (Drake, 2017); strength coaching (Francis \& Zarecky, 2017); cross-cultural coaching (Abbott \& Salomaa, 2017), somatic coaching (Strozzi-Heckler, 2014), etc.

From the "soul guide" to "Psy expert" to "managerial" to "network coach" (Western, 2012). 
handbooks (e.g., Palmer \& Whybrow, 2007; Cox et al., 2014b). Types of coaching in the dimensions concerned with responses to particular needs of organizations (Dimension 5) and emphases on specific elements of coaching (Dimension 6) are also constantly increasing (ICF, 2016; Bachkirova et al., 2017a). In addition to their growing number, organizational coaching is used in an expanding range of organizational contexts, such as business, government, education, health, charities, and so forth (Ridler Report, 2013; CIPD, 2015; ICF, 2016; Bachkirova et al., 2017a).

Within the context of growing differentiation in organizational coaching, such attempts to establish an identity for this practice also show a tendency to focus on differentiation from other practices without sufficient recognition of the relevant knowledge of other disciplines (Bachkirova \& Kauffman, 2009; Bachkirova et al., 2017a). This is noticeable, for example, in the strong desire of some coaching commentators to make coaching in organizations overtly distinct from other practices, such as consulting (e.g., Rogers, 2012); mentoring (e.g., Garvey, 2011), and counseling (e.g., Peltier, 2001). This often leads to a reactive tendency to swing to an unreasonable degree in the opposite direction. For example, in order not to be like consulting, coaching "should be" completely nondirective (Cox et al., 2014a; Joseph, 2014; Wilson, 2007) with "no knowledge" or advice being offered to the client (Rogers, 2012; Wilson, 2007). Similarly, in order not to be like therapy, coaching "should not touch on" anything associated with the client's past (Peltier, 2001), not work with emotions and personality issues (Berglas, 2002; Peltier, 2001), and avoid "reliance on the coach" (Peltier, 2001: xxx). Definitions of this nature create an illusion of simplicity and clear boundaries of practice, particularly to newcomers to this field: a typical misconception about coaching that educators have to deal with (Baker, 2015).

At the same time, there are some lonely voices in the literature who argue against restricting the identity of coaching in organizations at this stage of development. For example, Cavanagh (2009), argues that the lack of clarity in the identity of coaching "gives us ability to talk across silos" (Cavanagh, 2009: 112) at a time when appreciation of complexity of issues and the need for connectivity are required. Bachkirova and Kauffman (2009) and Bachkirova et al. (2017a) in their analysis of issues with definitions of coaching have also concluded that all definitions suffer from limitations, even when useful for practical reasons, and there are advantages in recognizing this state of affairs. Among these advantages is the opportunity for building on the extensive knowledge available as a resource from disciplines that are concerned with similar questions that coaches may be called upon to deal with (de Haan et al., 2010; Garvey, 2011).

What we advocate, therefore, is a two-fold approach to conceptualizing organizational coaching. First, as a starting strategy, this approach should aim at identifying in the most generic terms the core of coaching activity that would not be contested in the variety of the coaching approaches and would make use of knowledge developed in other disciplines. This core, for example, could be formulated noting the expansion of coaching in organizations as the result of a major shift in management learning from a prescribed, theoretical, supplier-led provision to a customized, contextualized, participative and experiential journey (Day, 2001) and to what Kempster and Iszatt-White (2012: 321) call naturalistic learning. This suggests a broad-based definition of organizational coaching as being "professional development through one-to-one conversation" (de Haan et al., 2010: 607) or as "individually facilitated learning" (Bachkirova, 2011: 7) in an organizational context. As a potential definition, this signals the importance of "not re-inventing the wheel" in principle and being able to build on knowledge accumulated by reference disciplines on the nature of learning, change, and development. An example of this would be the pragmatic notion of inquiry as developed by Dewey (1916), which we discuss later.

Second, we suggest that precision and high levels of detail in defining organizational coaching are currently unreasonable expectations in view of the complexity and diversity of organizational needs (Cavanagh \& Lane, 2012). The details of the coaching provision that we identify in Table 1 are variable depending on the context, models, purposes, and needs of the client and sponsor, with further variation provided by the orientation and background of the coach. Deeper understanding of all these elements is welcomed and hopefully forthcoming, but only possible with recognition of the complexity and diversity involved in the nature of this practice. We anticipate that new concepts, and even new language, will be developed in the future that might help in the holistic description of this practice, but at these early stages in the development of coaching as a discipline it is of utmost importance to keep the conversation open.

Therefore, what we see as the main problem is not the lack of common definition, but the potential 
danger of prematurely closing this conversation down by restricting the parameters for understanding organizational coaching. Such closure emerges from claims for exclusivity of any specific perspective on organizational coaching such as might be imposed by the adoption of different worldviews, "world hypotheses," and epistemological positions (Fishman, 1999; Pepper, 1942; Peterson, 1991). For example, a positivist approach, primarily concerned with achieving quantifiable science-based expectations, may lead to a view of coaching that is unnecessarily restrictive, such as Grant's description: “collaborative, individualized, solution-focused, results oriented, systematic, stretching, fosters self-directed learning, and should be evidence-based, and incorporate ethical professional practice" (Grant, 2006: 13). These types of definitions can be taken as evidence that organizational coaching is empirically underdeveloped and lacking the strength of more evidence-based models of practice (Fillery-Travis \& Lane, 2006), provoking an equally strong countercritique that evidencebased models are irrelevant to coaching practice due to their oversimplification and reductionist tendency (Garvey et al., 2014).

In contrast to these arguments around positivistreductionist approaches, social constructionists are developing descriptions of coaching as "a hermeneutic process" (Drake, 2017: 304) or even as "storytelling" (Reissner \& Du Toit, 2011: 248). These "postmodernist" preferences, although not unreasonably highlighting important processes of joint meaning-making that underpin many types of effective coaching practice in organizational settings, seem to reduce coaching to mere linguistic exercises: a position that is equally unsatisfactory given that their reliance on subjectivity can open the gates to self-deception (Bachkirova, 2015, 2016b). Other postmodern attitudes utilizing critical theory approaches highlight important issues of power and intercultural social contexts in coaching (Garvey, 2011; Shoukry, 2017; Western, 2012). These authors advocate a strong critical stance to coaching for lacking the depth of contextual understanding and following a blind adherence to undisclosed agendas. For example, Arnaud (2003: 1138) generalizes all coaching interventions as "bound by the cult of performance," only seeing that "the coach must help his or her clients constantly exceed their limits [in a context of] performance dictatorship:" a view that would be strongly denied by other practitioners and educators of coaching who see all types of coaching as learning and developmental (Cox \& Jackson,
2014; Bennett, \& Campone, 2017). Whichever side of this theoretical divide one's epistemological commitment falls on, the value of one's perspective is useful, but only partial, and needs to be considered valid among others with equal claims to validity. There seems to us to be a need for an overarching framework that embraces this multiplicity of perspectives and encourages interactive dialogue toward "integrative pluralism" (Mitchell, 2009).

In summary, we believe that arriving at a common definition of organizational coaching is a work in progress that requires the continuation of the interdisciplinary conversation. Many attempts to exclusively position coaching tend to be influenced by epistemological attitudes that separate rather than integrate the discipline, and thus, limit the crossfertilization of ideas (Cavanagh \& Lane, 2012; Bachkirova, 2017). Our view is that this situation is particularly challenging for educators of coaching. Although it is possible to acknowledge and even appreciate the interdisciplinary richness of coaching, this inevitably creates significant diversity in terms of the learning expectations for coaching and leads to challenges for educators and trainers to develop inclusive, coherent, and integrated programs that satisfy such expectations (e.g., Lane, 2017; Gray, Garvey, \& Lane, 2016; Bachkirova \& Lawton Smith, 2015; Athanasopoulou \& Dopson, 2015; Bachkirova et al., 2017b).

To address these challenges, we explore the potential of philosophical pragmatism to provide a coherent epistemological platform for keeping this dialogue open for the benefit of coaching as an applied discipline (Fishman, 1999; Pihlstrom, 2015; Rumens \& Kelemen, 2016). There are very good reasons for taking a fresh look at what pragmatism has to offer in terms of a deeper understanding of the nature of coaching. The focus on action advocated by pragmatism promises to be an important addition for describing a core feature of coaching. The value of this idea can be demonstrated through a deeper understanding of the nature of the coaching process, in determining a pivotal purpose of organizational coaching and in the flexible attitude of the practitioner in any coaching relationship. We discuss these themes in the section, Coaching Practice Through the Lens of Pragmatism, to show how pragmatist ideas can enhance both the theory and practice of organizational coaching, but first we develop our integrated position on philosophical pragmatism as a theoretical framework for organizational coaching. 


\section{PRAGMATISM AS A UNIFIED PHILOSOPHICAL POSITION}

Often leveled against pragmatism is that it fails to present a coherent philosophical position and that the differences between its classical proponents, most notably Peirce, James, and Dewey, but also including Schiller and Mead, are greater than those beliefs and attitudes that they hold in common (James, 1907, 1982; Hildebrand, 2003; Haack, 2006). Quite why this focus on differences as being indicative of incoherence is so strongly made against the pragmatists, and not against the empiricists, rationalists, existentialists, and logical positivists, is a point worth exploring, but does not fall within our remit here. Philosophy does not proceed through arriving at consensus, but by progressing through argument and counterargument, and this is as much the case within "philosophical schools" as it is between schools. There is as much difference in detail, we argue, between Descartes and Spinoza as "rationalists," and as much similarity as there is between the pragmatic views of C. S. Peirce and those of John Dewey. In both cases the difference is found in the detail, not in the general philosophical dispositions: There is enough of a common thread between Descartes and Spinoza to confidently identify a rationalist as there is to identify a pragmatist when considering the distinctions drawn between Peirce and Dewey.

Also likely is that the case for the strength of feeling concerning the discontinuities between pragmatists is generated from two main sources: First, one might recognize the professional desire of some later pragmatically inclined philosophers to identify with the hard-headed logic and scientific endeavor of Peirce (Haack, 2006). The aim here is perhaps being to provide philosophical "credibility" in the face of analytic disapproval and to avoid the accusations of relativism and irrationalism that have been regularly directed mostly against James, sometimes against Dewey, and frequently against vociferous neopragmatists, critical of the Anglo-American analytic tradition, such as Richard Rorty (Pihlstrom, 2015). Second, we have Peirce's own clear objections made to James concerning what Peirce saw as a clear misrepresentation of his ideas made by James in relation to developing certain pragmatic themes, in particular those to do with James' notion of "truth" and his interpretation and application of Peirce's "pragmatic maxim" (Haack, 2006). However, it has never been the case that initiating a methodological approach gives any one individual unchallengeable rights in determining how those ideas should be further developed by others who share similar interests. Furthermore, as Menand (2001) shows, the origins of philosophical pragmatism are difficult to trace to one clearly identifiable source, and the idea that pragmatism originates solely with Peirce is highly questionable.

Nevertheless, it would be unreasonable to deny that there are clearly discernible differences between the three main figures in the development of pragmatist thinking (Pihlstrom, 2015; Haack, 2006; Rorty, 1980b) and some commentators (e.g., Tallisse \& Aikin, 2008; Pihlstrom, 2015), supportive of a pragmatist approach to philosophical inquiry, have been happy to acknowledge the breadth of discourse that these differences bring with them, identifying this as a strength rather than a sign of weakness. For example, Tallisse and Aikin hold that "the conflict among pragmatists over central philosophical questions-and indeed, over the character of pragmatism itself-is a sign of intellectual health rather than crisis" (Tallisse \& Aikin, 2008: 25). Pihlstrom argues that pragmatism "indeed, lives from its genuine philosophical problems. Its depth lies precisely in its not having provided any final, ultimate theory about anything" (Pihlstrom, 2015: 5).

To the extent that there are differences, we can crudely summarize these as Peirce's primary concern with establishing a logic of scientific inquiry; James' chief interest relating to the variations that occur in subjective experience; and Dewey as mostly interested in the relational aspects of democratic community and pedagogic processes. That these differences are upheld and frequently accentuated by those who follow in their footsteps (Pihlstrom, 2015) is, we suggest, nothing more than an indication that each of the leading pragmatists valued certain aspects of human activity as more salient than others. We also argue this indicates that from the principle ideas that define a pragmatic approach to arriving at a philosophical understanding of any topic worthy of philosophical investigation are widely applicable and bear useful fruit in many ways. It is, nevertheless, important to emphasize that none of these specific preferences that can be detected in the work of the thought-leaders of pragmatism are mutually exclusive, and that by drawing the threads together with due care and attention to argument and implication, we can clearly see how pragmatism provides us with a rich and integrative method for approaching many of the fundamental issues concerning what it is to be human (Pihlstrom, 2015; Fishman, 1999). The common threads that emerge from integrating 
the classical pragmatists in this way identify what might best be described as an "attitude" (Martela 2015b; Burke, 2013).

The pragmatist attitude that we see as our integrated position on pragmatism, and believe to be most useful for the development of a theoretical base for organizational coaching, acknowledges that:

- Our experience of the world and our ability to navigate it are real, but our access to that reality is only ever, at best, partial.

- Our knowledge of this reality is arrived at through our interacting with the external world in a bidirectional process, where the world acts upon us, and we act upon the world; therefore, we only know the world through experience, and "experience" is best understood at an ontological level in terms of relationships.

- Because of this processual relationship, fixed ontologies and epistemological attitudes such as positivism, constructivism, truth as correspondence/ coherence, etc. fail to capture the reality of experience and set limits to the dialogic processes through which knowledge is generated.

- Knowledge generated in this pragmatic way is verified by being tested against experience through action while being recognized as fundamentally fallible and open to abandonment if better strategies for making sense of experience become available.

- Experience, while rooted in subjectivity, only gains meaning intersubjectively; thereby, knowledge building becomes a communal enterprise demanding cooperation and dialogue to be effective.

In light of this interpretation of what we identify as the common thread that runs through all of the classical proponents of pragmatism (Peirce, James, \& Dewey), we argue that philosophical pragmatism is best positioned as a "theory of action" (Kilpinen, 2009) and as an epistemological attitude that facilitates inquiry, rather than seeking to shut it down (Martela, 2015a).

\section{Pragmatism and the Facilitation of Dialogue for Theory Development}

Recognizing the importance of the dialogue for further development of the theoretical knowledge of organizational coaching, we believe that pragmatism can be seen as a philosophical framework that enables and encourages such dialogue to take place (Fishman, 1999; Pihlstrom, 2015; Rumens \& Kelemen, 2016).
This is important in light of the situation when dominant worldviews and corresponding epistemological positions in academia are apparently caught in multiple dichotomies and claim exclusivity of their competing views on knowledge and practice, thereby preventing the continuation of multidimensional dialogues (Fishman, 1999). Similarly, we believe that pragmatism has the capacity to transcend the disjunctions that limit our understanding of organizational coaching, how it is conceptualized, practiced, and can be developed.

We argue that two features of pragmatism suggest its potential for being a core philosophical framework that is able to facilitate a theoretical dialogue important for organizational coaching. The first is "integrative pluralism," which argues for expanding epistemic perspectives in a way that "embraces both traditional reductive and new, multilevel, context dependent approaches" (Mitchell, 2009: 2). This feature of a pragmatic position provides support for a claim that pragmatism can be successfully interpreted as a meta-perspective, framing a discourse in which theoretical paradigms that are normally viewed as being in competition with each other benefit by being understood as complementary voices that make up the community of inquiry looking to make sense of what it is to be humanbeings-acting-in-the-world (Fishman, 1999; Pihlstrom, 2015). Pihlstrom argues that pragmatism is not a single way of knowing, or a single categorical framework, "but a meta-framework for explicating and assessing the different systems we employ for categorizing reality" that utilizes a methodology that involves "knowing reality pluralistically and non-reductively, considering all the perspectives and standpoints that might be significant for the matter at issue-letting different voices be heard" (Pihlstrom, 2015: 3). This also encapsulates an inherent ethical tendency in pragmatism toward democratic process: an important feature in of John Dewey's thought (Putnam, 2017).

The second feature that describes pragmatism is a "spirit of open-endedness" (Pihlstrom, 2015: 5), implying that any further theoretical and philosophical developments will be welcome. By understanding reality as a relational flux with which we have to proactively engage so as to impose some sort of manageable order enabling us to cope and survive (James, 1904, 2000; Dewey, 1925), pragmatists generally understand knowledge not as something fixed and absolute, but as "consisting of contextually limited guidelines" (Fishman, 1999: 108). This means that for the pragmatist, knowledge (the sense that we 
collectively make of reality) is tentative, fallible, and incomplete (Martela, 2015a), and it can be enhanced by new contributions from any party participating in the dialogue. Thus, according to Putnam (2002: 7) pragmatism is an on-going inquiry into the "interactions between a human organism and its environment with the aim of "explor [ing] and interrogat[ing] the interrelationship between rationality, knowledge and everyday practices/ experiences." We argue that it becomes inevitable that the use of knowledge in practice, when seen in this light, implies that all stakeholders in the coaching field would benefit from adopting an attitude of holding theories lightly, being ready to be surprised, and admit mistakes. It implies the importance of research and development of theories, but also a need to doubt and to nurture our hunches as a sense of "what may be."

Perhaps the most important dichotomy that pragmatism seeks to abolish is that which is drawn between theoria and praxis. Pihlstrom (2015) argues that the common thread that runs through the thinking of the classical pragmatists is that they are all intent on overcoming the false dichotomy that had been used, from Plato onward, to place a substantial barrier between theoretical knowledge and practical action. For the pragmatist, there is no distinction: Knowledge is action and theory is practice (Kilpinen 2009). This is important to highlight because of the typical confusions that continue to exist in coaching between philosophical pragmatism and the ordinary language use of the term (Cox \& Jackson, 2014; Jenkins, 2016). Generally, it is held that "to be pragmatic" is to adopt an attitude of "making do" simply to arrive at useful solutions for dealing with problems in a sensible way that suits the reality of the situation, which can be identified as "crude pragmatism" (Jenkins, 2016). As a philosophical position, pragmatism constitutes a conceptual perspective that successfully informs important epistemological and ontological issues (Pihlstrom, 2015). Unfortunately, the former interpretation has been dominant in coaching, particularly at the early stages of establishing its academic credentials. Jackson, for example, explicitly addresses a "can do" culture of pragmatism prevalent at the early stages of coaching as a market-led activity. He also critiques this position as it "obscures issues of practice, professional development and the maturation of the profession" (Jackson, 2004: 75). Such confusions tend to overlook pragmatism's applicability as a philosophical position in that they miss the pragmatist's clear identification of the intrinsic relationship between theory and practice: its most clearly identifiable feature (Fishman, 1999).

\section{Pragmatism As a Theory of Action}

From the very first statements of pragmatic intent (Peirce, 1878, 1955a), it was apparent that the meaning of concepts, thoughts, and beliefs are to be found in the practical effects that such propositional attitudes bring to bear, and any such practical effects can only be revealed by being enacted in the world. As Peirce argues, "thought is an action, and. . . it consists in a relation. ... [W]e shall be perfectly safe so long as we reflect that the whole function of thought is to produce habits of action. ... .To develop [a thought's] meaning, we have, simply to determine what habits it produces, for what a thing means is simply what habits it involves" (Peirce, 1878, 1955a: 28-31). This is known as the pragmatic maxim and, we believe it demonstrates something of the fundamental importance of the relationship between conceptualization (forming ideas about how the world is) and action (acting upon those ideas and verifying their veracity, or utility, through consequence, or "sensible effect" as Peirce might put it).

Peirce's maxim provides the groundwork for the pragmatic insistence, common also to James and Dewey, that knowledge emerges from actual life itself, from the struggle to adjust to the problem of living which is constituted by acting-in-the-world (Hogan, 2009; Martela, 2015a). Peirce's initial motive for developing his version of the pragmatic method was primarily to arrive at a non-Cartesian epistemology (Rockmore, 2002), whereby knowledge is liberated to simply concern itself with being that which we need to know to alleviate doubt sufficiently enough to act. James and Dewey further enhance this by developing an approach to philosophical inquiry that is essentially anti-reductionist, pluralistic, and contextualist (Pihlstrom, 2015).

The move that Peirce makes is a response to what Bernstein later identifies as "Cartesian anxiety" (Bernstein, 1983), referring to Descartes' move to define knowledge only in terms of certainty. This provides pragmatism with a level of epistemic flexibility that was then unavailable to other modes of the Western philosophical tradition. Philosophical concern is no longer aimed at the establishment of Truth and Certainty as the fixed foundations of rationality, but more to do with the therapeutic and communal enterprise of making sense of experience (Rorty, 1980a). Dewey describes this as the pragmatist's attempt to avoid engaging in the 
"spectator theory of knowledge," a position common to both anti-realist and realist-reductionist approaches to philosophical inquiry (Dewey, 1929, 1980: 245). For the pragmatist, epistemology involves not taking a privileged, disengaged perspective (Rorty, 1980a), but understanding that we develop knowledge through embedded interaction with our environments.

This emphasis upon action is important, we argue, because it identifies pragmatism as providing a philosophical framework that is fully grounded in active participation in the world and in the human condition as it arises from our actively being-in-theworld. Although it may not always be easy to establish a single coherent positive doctrine by which pragmatism can be clearly defined, a close reading of the classical pragmatists points to a strong sense in which all forms of inquiry are aimed at humanity making sense of the process of experiencing through active engagement, not by sitting on the sidelines in the role of detached observer. Martela (2015b: 202) puts this nicely when he says:

...the human condition inherent in pragmatism acknowledges that our way of experiencing involves sense of activity, purposefulness and resistance. Taken together, these three dimensions of our relation to experience amount to an understanding that the human condition means an active interest in developing the stream of experience in certain directions. Our primary interest as regards the world is about attempting to navigate our way within its constraints as best as we can.

Our identification of pragmatism as a theory of action is particularly relevant for providing a suitable theoretical framework for organizational coaching. It highlights what is, in our view, a fundamental aspect of coaching in an organizational context as learning associated with action. The engagement with knowledge in coaching is not concerned with one true understanding of the situation and the best solution for a problem, but aims at overcoming doubt where it prevents the client from acting. There is no guarantee that the understanding generated in the coaching process is sufficient or that the course of action is the right one; further adjustments to these may well need to take place. However, action, as an essential element of being human, is necessary to function in the world and coaching, and we argue, aims to facilitate just that by assisting the client in becoming ready to act.

This pragmatic understanding of the inextricable link between learning and action further identifies a key element differentiating coaching from the closely related and more established disciplines of psychotherapy and counseling (Cox et al., 2014a). Organizational coaching (and perhaps coaching in all its different modalities) aims not at healing an emotional disturbance or directly increasing the clients' sense of well-being (Grant, 2013; Kenworthy, Passarelli, \& Van Oosten, 2014), but has as its focus enabling clients to develop their capability to act on their environment (Cocivera \& Cronshaw, 2004; Bachkirova, 2011; Spence \& Deci, 2013; Clutterbuck \& Spence, 2017). In this regard, we could say that the purpose of organizational coaching is not so much concerned with well-being, but fundamentally, with well-acting. In coaching, as in pragmatism, human purposive action is central to the understanding of what it is to be human (Clutterbuck \& Spence, 2017). Pihlstrom remarks of Dewey, in this regard, "just as in Peirce and James, human purposive action is a cornerstone of his pragmatic naturalism" (Pihlstrom, 2015: 15). We argue that it is equally a cornerstone for organizational coaching practice and theory, and therefore, needs to be more prominent than it has been so far.

We discuss specific features of coaching in the light of philosophical pragmatism and their implications for coaching as a discipline in the next section. Here, however, we finish with a more general suggestion for educators of coaching whose task is to design and teach training, and particularly, postgraduate programs. As we have argued, an overarching framework of philosophical pragmatism that fully appreciates the interdependence of theory and practice, accommodates multiple traditions and approaches, and places action at the center of the coaching enterprise can serve as a solid foundation that would hold their programs together. While emphasizing a focus on action as a distinctive element, it would also provide a spacious "container" for debate and promote scientific attitude and the growth of new ideas in organizational coaching.

\section{COACHING PRACTICE THROUGH THE LENS OF PRAGMATISM}

So far, we have argued that organizational coaching needs more attention paid to theoretical understanding for further development as a discipline. In this section, we extend our argument into practice by showing how three different ways of seeing coaching as a pragmatic enterprise with an explicit element of action furthers theoretical understanding of this practice. First, we explore the nature of the coaching 
process in its most generic features and show how pragmatism helps to explain why coaching works, and why it sometimes does not. We then discuss what is a significant contribution that pragmatism makes to one of the fundamental issues of coaching practice in its quest for conceptualization of core identity: its purpose and aim. We conclude with considering how coaches can apply a pragmatic epistemological attitude to the inevitable diversity of coaching traditions without losing the coherence of their own approaches and style.

\section{Coaching As Learning Through Experience and Joint Inquiry}

In this section, we show an important correspondence between the pragmatist account of the way humans learn and function in the world and the process of organizational coaching. From the literature currently available concerning the theory and practice of coaching, it is possible to discern three generic features: learning through experience (e.g., Cox, 2013; Bennett \& Campone, 2017; Rogers, 2012; Athanasopoulou \& Dopson, 2015); reflecting as a form of learning (e.g., Shoukry, 2014; Cox, 2013; Wilson, 2007; Bachkirova et al., 2017b); and the coaching relationship as the essential condition for coaching (e.g., Baron \& Morin, 2009; de Haan \& Duckworth, 2013; de Haan \& Gannon, 2017; Myers, 2017). We argue that inquiry, a core concept of pragmatism (Dewey, 1916, 1938; Buchler, 1955), not only allows an integration of these essential characteristics of coaching into a meaningful whole, but also provides a persuasive explanation as to the value that they bring to coaching outcomes.

Learning through experience. The conceptualization of coaching as individually facilitated learning is widely represented in the coaching literature (Lane, 2017; Bennett \& Campone, 2017; Bachkirova, 2011; Cox, 2013; Rogers, 2012; Athanasopoulou \& Dopson, 2015). Theories of experiential learning, such as those offered by Kolb (1984, 2014), Knowles (1978), (Knowles, Holton, \& Swanson, 2015), and Mezirow (1990), are promoted by educators of coaching (e.g., Cox et al., 2014b) as fundamental for the theoretical understanding of this practice. At the same time, as Thayer-Bacon (2015) points out, this theme of learning (i.e., "making sense of experience") through engaged action with the world as both experiencing and enacting agent is common throughout classical pragmatism, occurring not only in Dewey's philosophy of education, but also in the work of Peirce, James, and Mead, and continues to be taken up by its neo-pragmatist proponents (ThayerBacon, 2015). It is apposite that Dewey's identification of a fundamental principle of learning that he defined as his "technical definition of education" also describes the core of coaching very well (Dewey, 1916: 89):

[Learning] is that reconstruction or reorganization of experience which adds to the meaning of experience, and which increases ability to direct the course of subsequent experience.

This alignment between the idea of learning in pragmatism and coaching can be also extended by inclusion of another concept that features in pragmatist thinking: inquiry (Dewey, 1938), which not only makes learning more specific and practical, but also adds significantly to the understanding of how and when coaching works (Fendler, 2003; Rodgers, 2002; Jenkins, 2016). It illuminates both the nature of the coaching process and what has to be in place for an effective coaching engagement to occur, as the following clarifies.

Dewey describes inquiry as "a controlled and directed transformation" of a puzzling indeterminate situation, which becomes transformed into a situation that enables the "best solution for now" (Dewey, 1938: 72). By "situation" Dewey means "not a single object or event" but the "contextual whole" of experience (Dewey, 1938: 72). A situation is conducive to change when it is "uncertain, unsettled, disturbed" (Dewey, 1938: 109) and requires equilibrium to be restored. People engage in inquiry when their beliefs about reality and corresponding habits fail to guide them successfully to what they hope to achieve. They have a sense of doubt that needs to be overcome, and through inquiry, they attempt to restore their system of beliefs in such a way as to provide warranted guidance for future action (Peirce, 1878, 1955b; Dewey, 1938).

In considering the concept of inquiry in relation to organizational coaching, it is important that inquiry is understood as not just problem-solving: "Problems do not pre-exist inquiry" (Hildebrand, 2013: 68); they are formulated in the process of inquiry. In the same way the impetus for participating in coaching does not necessarily have to come from a problem: It may have various origins, such as a need or desire to make a positive change. What is more important is that full engagement with the coaching process implies a particular state of mind that is conducive to generating a change. This state of mind is fittingly indicated by the process of inquiry described by Dewey as a first phase in the pattern of inquiry. We 
summarize this pattern by Dewey (quoted in Tallisse \& Aikin 2008: 120) as follows:

(1) Perplexity, doubt due to being in a situation whose full character is undetermined.

(2) A tentative interpretation of the given elements with their tendency to effect certain consequences, forming a hypothesis.

(3) A careful exploration of all attainable considerations to clarify the problem.

(4) An elaboration of the tentative hypothesis to make the problem more precise in light of a wider range of facts and considerations.

(5) Taking one stand upon the projected hypothesis as a plan of action, applying and doing something to bring out the anticipated result, and thereby, testing the hypothesis.

The first phase indicates the state of mind important for the engagement in the inquiry: a sense of disequilibrium. The second phase normally occurs through individual reflection that coaching clients may undertake as part of their normal reflective practice prior to coaching (Schön, 1987; Gray, 2007), resulting in the realization that additional perspectives are needed to make progress. We see Phases 3 and 4 taking place during the coaching sessions, where the client explores the situation in order "to make sense," but doing so "in the light of what other people have concluded in similar circumstances" (Pring, 2014: 65). The 5th phase is action: The clients' application of ideas generated in the coaching session to actual situations. Results arising are further explored in the following sessions to assess the consequences of the action or to create material for continuation of the inquiry.

Understanding the coaching process as an inquiry according to Dewey's analysis (1938) has important implications for both theory and practice. First, it suggests a potential explanation for those situations when coaching is unsuccessful (Rogers, 2012; Athanasopoulou \& Dopson, 2015). The first item of the inquiry that we call "disequilibrium" addresses the issues with incentives for coaching. Apart from the skills of the coach and quality of coaching relationship, various studies show that the client's so-called "readiness to change," which strongly influences the quality of their engagement and commitment, is one of the most important factors in the successful outcome of coaching (MacKie, 2015; Rogers, 2012; Myers, 2017). However, what constitutes such readiness, and how it is associated with the immediate situation, is far from clear and is still subject to debate (Brug, Conner, Harre, Kremers,
McKellar, \& Whitelaw, 2005; Baron \& Morin, 2009; MacKie, 2015; Athanasopoulou \& Dopson, 2015).

The progress made in understanding "readiness" is slow because the attempts to explain it are stuck within the old psychological paradigm of seeing this phenomenon as located within the individual (Avolio \& Hannah, 2008). In contrast, conceptualizing the coaching process as a form of Deweyan inquiry implies that the client's readiness is embedded in the situation. It suggests that any successful coaching engagement requires a state of mind in the client generated by their confrontation with an indeterminate complex situation and accompanied by the doubt that current beliefs and habits are sufficient for future actions. Without such a state of mind in the client, coaching falls short of the drive and energy required for productive work. For example, when coaching is offered as part of the "executive package" or leadership program, and clients do not experience the situation as described above, the process struggles to stay meaningful, and this is a subject of regular concern for coaches (Rogers, 2012; Athanasopoulou \& Dopson, 2015; Myers, 2017). This way of conceptualizing coaching readiness suggests that coaching "starts before it starts," and the quality of contracting for it has to be discussed in this light both in coaching practice and in coaching education. This repositioning of the coaching process also suggests different research questions and potentially new propositions about the conditions for effective coaching.

Another explanation for issues affecting the quality of coaching can be explained by identifying missing phases in the inquiry process. Hildebrand (2013: 69) reminds us that by describing the pattern of inquiry Dewey did not mean "to describe how people always think but rather how they would think if they followed more exemplary kinds of inquiry, like those found in the empirical sciences." It is possible to postulate then that coaching may not be as effective as it could be if not all the phases of inquiry were present in the coaching process. For example, if the initial goal of coaching presented by the client is taken for granted, and the process moves swiftly to generating options (hypotheses for how the goal can be reached) but misses the phase of identifying and clarifying the problem, the process may become superficial and focused on marginal issues that may not need to be the object of inquiry in the first place (Clutterbuck \& Spence, 2017). This way of conceptualizing organizational coaching has immediate implications for practitioners and educators of coaching. 
Reflecting as a form of learning. The next area of application of the pragmatist notion of inquiry to coaching is the process of reflecting, which is considered to be a cornerstone activity of coaching (Gray, 2007; Cox, 2013; Athanasopoulou \& Dopson, 2015). Although the essential role of reflecting is recognized in coaching literature, how it operates in practice has had less attention (Cox, 2013). In Dewey's work, however, we find a description of not only the way reflection/inquiry operates in terms of phases, as outlined in the previous section, but also in terms of principles that provide a broad psychological framework of attitudes and conditions important for the quality of this process.

Rodgers (2002: 845) describes Dewey's four criteria of reflection in this way:

(1) Reflection is a meaning-making process that moves a learner from one experience into the next with deeper understanding of its relationships with and connections to other experiences and ideas. It is the thread that makes continuity of learning possible, and ensures the progress of the individual and ultimately, society. It is a means to essentially moral ends.

(2) Reflection is a systematic, rigorous, disciplined way of thinking, with its roots in scientific inquiry.

(3) Reflection needs to happen in community, in interaction with others.

(4) Reflection requires attitudes that value the personal and intellectual growth of other.

It could be argued that all these principles are essential for any genre of coaching and are often recognized as such (Cox \& Jackson, 2014; Berger, 2012; Hunt \& Weintraub, 2004). However, some of the elements in these principles can be observed in different types of coaching more than in others. For example, the elements that emphasize personal and intellectual growth and the progress of the individual, and ultimately society, are more explicitly stated in developmental coaching in comparison to performance or skills coaching (Cox \& Jackson, 2014; Bachkirova, 2011; Berger, 2012). When coaches develop a rationale for their approach to practice, these differentiators can be used for making the offering more explicit. More importantly, these principles can be useful for coaching educators in the design of programs that are consistent, not only in terms of structured knowledge and honing of practical skills, but also grounded in wider human values.

Coaching relationship as the essential condition for coaching. A final feature of the coaching engagement that is touched on by the idea of coaching being an inquiry follows directly from Rodgers' third criterion above (2002: 845$)$. It speaks directly to the nearly universal acceptance of the importance of the coaching relationship for a successful coaching outcome (Hunt \& Weintraub, 2004; de Haan \& Gannon, 2017; Myers, 2017). Such a prominent role for the coaching relationship might be about the value of considering the situation that is the focus of the coaching engagement from as many angles as possible. As such Weick (2008), following ideas from William James, argues, "we must actively and continually solicit the input of others, and be willing to revise our own viewpoints accordingly" (2008: 91). This, however, is only one kind of benefit that the coaching relationship can provide. It cannot, by itself, explain the scale of support for this factor that is evident in both the conceptual literature and empirical studies of coaching (e.g., Wilson, 2007; Rogers, 2012), also considering that the relationship is often described in terms, such as rapport, bonds, trust, transparency, commitment, etc., that, in themselves, require further explanation as to how they are manifested or achieved (de Haan \& Gannon, 2017).

We propose that the effect of the coaching relationship is due to the client and coach essentially becoming a small but, therefore finely tuned, community of inquiry: an idea that consistently features throughout the writings of Peirce, James, and Dewey (Buchler, 1955; Campbell, 1995). This idea emphasizes that understanding and knowledge can only emerge from communal enterprise and cannot be the product of individuals removed from social engagement. We believe that trust and rapport are byproducts of closely working together on a topic of inquiry that is important for the client. Some support for this position can be found in recent research on the coaching relationship (Grant, 2014; Gessnitzer \& Kauffeld, 2015). The features of the relationship that were most associated with the outcome of coaching were not so much about esoteric "bonding," but concerned with goal- and work-focused coaching relationships.

We argue that for practitioners and educators, conceptualizing the coaching relationship as joint inquiry, in line with the pragmatist concept of community of inquiry, highlights a dimension and focus for improvement that is potentially far more useful than currently emphasized alternatives. For example, de Haan and Gannon (2017: 198) note in their analysis of various studies on coaching relationships, that each client requires "unique tailoring of 
the bond in the coaching relationship," something that seems to remain "esoteric" and vague. In contrast, according to a pragmatic attitude, the focus of the coaching relationship shifts to more concrete activities that are recognizable as inherently "coaching," such as listening, questioning, reasoning, deliberating, challenging, developing the client's problem-solving capacity and (importantly), considering the effects of these on their interaction. "[O]pening up the situation to increasingly complex and nuanced observations, thoughts, feelings, and so forth" (Rosenbaum, 2015: 328) enhances understanding not only of the situation, but also of how both client and coach make meaning. This mutual understanding and consideration of the effects of their actions on the quality of their relationship are tangible factors that consequently facilitate the development of relationships. This is something concrete that coaching educators can focus on when they engage their students in learning about the coaching relationship.

As mentioned before, we do not see joint inquiry as a description of what the coaching relationship must necessarily be, but how it would become if the engagement between the coach and client is fully effective. Naturally, it should be acknowledged that there are many complex factors that could undermine coaching as a joint inquiry, such as conflict of interests (Iordanou, Hawley, \& Iordanou, 2017); power relations (Garvey, 2011; Welman \& Bachkirova, 2010); organizational politics in the three-way contracts (Korotov, Florent-Treacy, Kets de Vries \& Bernhardt, 2012), and so forth. In fact, organizational issues are nearly always not only the context of coaching, but essential elements of the situation that the client perceives as a disequilibrium which leads to the readiness for coaching and becomes the theme of coaching conversations (Garvey et al., 2014). Organizational sponsors for coaching are not part of the joint inquiry unit, but the relationship with them is an integral factor in creating a successful joint inquiry prior to the coach starting one-to-one work with the client.

\section{The Ultimate Aim of Organizational Coaching}

The second example of how pragmatist thought can advance the theoretical understanding of organizational coaching is related to an issue rarely addressed in any explicit way in the literature of organizational coaching: the question of what coaching is for. A possible explanation for the lack of attention to this topic is that it inevitably takes the debate into the realm of human values and moral and ethical questions: a domain of philosophical concerns from which easy answers are rarely forthcoming. Any attempts to address this topic tend to acknowledge several aims rather than an overarching purpose. For example, Cox et al. (2014a) drawing on the three paradigms of practice in HRD by Bates and Chen (2004) - to encourage learning, to increase performance, and to enhance meaning in work-argue that various types of coaching are used to serve these general aims. Such multiple aims do not present a problem, providing they maintain compatibility. However, the need for overarching purpose becomes significant when any of these aims start to contradict another.

For instance, it is possible to identify a number of intrinsic and persisting debates in the coaching field that could already benefit from taking a broader philosophical perspective on the value and purpose of organizational coaching. In this regard, the insights that philosophical pragmatism provides into the way humans learn and act facilitates an opportunity for educators to offer more specific guidance to students. Such debates include "non-directivity of coaches" versus "coach as an expert" (e.g., Joseph, 2014; Wilson, 2007; Rogers, 2012); "individual agenda" versus "organization agenda" for coaching assignments (e.g., Segers, Vloeberghs, Henderickx, \& Inceoblu, 2011; Hawkins \& Smith, 2013; Athanasopoulou \& Dopson, 2015); and the choice of criteria for effectiveness of coaching (e.g., Grant, 2013). The issues represented by these debates are interconnected because they require identifying criteria that determine which actions of the coach can be considered as desirable and "working" in a given context.

For example, a well-established discourse of coaching concerns the importance of the self-determination of the client, which is associated with personcentered approaches (Joseph \& Bryant-Jefferies, 2007; Joseph, 2014). The coach refrains from explicitly influencing how clients perceive and deal with their issues and life tasks, believing that clients already possess the resources needed to act (e.g., Rogers, 2012; Wilson, 2007). Only the client should determine the content of the coaching conversation, and the coach facilitates the process of meaning-making and planning of actions (Cox \& Jackson, 2014). There are other conceptualizations of organizational coaching, for example, those inherited from consulting or psychotherapeutic practices, in which the expertise of the coach plays a more prominent role. For example, in psychoanalytic 
coaching, Arnaud (2003) argues a coach has knowledge that is above that of the client, which should be utilized to guide the client to develop their thinking "in the direction judged pertinent." In this expertbased position, the coach is expected not only to explain the origin of the clients' problems (Arnaud, 2003: 1143), but to also indicate preferable courses of action. This latter discourse is less popular, as coaches recognize the importance of the need for autonomy in the motivation of action (Deci \& Ryan, 2000; Spence \& Deci, 2013) and make the assumption that the client is more likely to persevere with a course of action that has been self-initiated (Athanasopoulou \& Dopson, 2015).

However, from the position of the ultimate aims of coaching, this idea of the client being the main judge of what is needed and what works might still be questionable. It explicitly privileges the individual context in terms of determining and evaluating potential outcomes, which may lead to coaching being in service of too narrow utilitarian needs and perhaps justifies accusations aimed at the coaching industry concerning disastrous decisions leaders sometimes make while being coached. In a theoretical valueoriented argument set by Bachkirova et al. (2017b), this can be seen as an expression of value-neutral instrumentalism, a philosophical position that creates many problems in the education and assessment of coaches, but also in relation to the evaluation of ethical decisions in complex situations. According to the value-neutral instrumentalist, coaching is seen as "a professional service provided to clients in order for them to achieve their goals, whatever these goals might be" (p. 36, emphasis added).

In contrast, there are well-known figures in the field who advocate the role of coaches in expanding the client's responsibility for wider organizational and societal needs (Hawkins \& Smith, 2013), or influencing leaders in becoming, for example, more spiritually oriented (Whitmore, 2008). These theoretically consistent, but ideologically driven positions clash with the cherished principles of autonomy and self-determination of the client. They might also present a problem when organizational needs are strongly prioritized in three-way contracts by shaping individuals according to the organization's short-term needs, thereby stifling those who might otherwise be able to challenge the status quo and bring new ideas with wider and long-term consequences (Garvey, 2011; Shoukry, 2017).

To overcome the disjunctive nature of these debates, benefit could be gained from a higher order of conceptualization and adopting wider perspectives, such as a holistic view on the relationship between ends and means and the potential direction of the learning process human beings undergo: a key aspect of John Dewey's formulation of philosophical pragmatism. Dewey argues against the separation of "means" from "ends," seeing them as "intrinsically continuous" (1916). According to him, to define these relationships as being in some way antagonistic does not do justice to the continual adjustment to circumstances that typifies most action. For example, Pring (2014), in developing Dewey's position, notes that "the more observant one is of the present circumstances the more alternatives one sees as possible outcomes-the more connection one will see the 'end-in-view' to have with other events" (2014: 43). At no stage can it be said "mission accomplished" because what previously had been an "end-in-view" may become a stage in some further activity. In line with this argument, coaching could be seen as both a means and an end: as a process with goals emerging, being pursued, and transforming into new ones as part of the process (Clutterbuck \& Spence, 2017).

This view on means and ends then has to be combined with another of Dewey's central ideas concerning the natural human disposition to inquire and to learn as being a key feature of the organism's survival strategies evolved to adapt to changing circumstances (Dewey, 1916). This needs to be further contextualized by understanding the human organism as not only biological, but also an intensely social being that, through interaction with others, accumulates the "wisdom of the race" that enables it to grow as a living, experiencing, and problemsolving entity (Pring, 2014: 45). Dewey (1916) argued that the act of living requires the interaction of this received wisdom and acknowledgment of learning from others with a continuous engagement and active experimentation with life tasks. Without this interactive dynamic process, our experiences would "remain hermeneutically sealed off from each other" (Pring, 2014: 48), an outcome that would lead to their, and our, impoverishment. In this light, coaching provides an additional opportunity for such interactions, thereby facilitating the means for the sharing of current concerns and encouraging experimentation with the world by means of new actions (Cox, 2013; Bachkirova, 2011; Bennett \& Campone, 2017). This allows us to frame coaching as one of the many interactional and experimentation opportunities in the natural process of learning in a social context: a joint and active inquiry. 
In addition to seeing learning as a natural adaptation, Dewey postulates that living and learning transform our experiences leading to a continuously increasing maturity of the individual that is a life-long process (Dewey, 1916). Most importantly, according to Dewey, this growth has no end other than further growth: "Our net conclusion is that life is development, and that developing, growing, is life" (Dewey, 1916: 50). Although his argument was related to education as growth, the same could be argued in relation to coaching as a particular type of individually facilitated type of learning (e.g., Bachkirova, 2011). By providing a tailor-made opportunity for processing, reformulation, and transformation of experience, coaching facilitates the development of the client's capability to deal with further experiences and to adapt to new situations. Following Dewey's statement about education, we re-state that the aim of coaching at every stage is "an added capacity for growth" (Dewey, 1916: 54). Therefore, in affirming this as one of the main intentions of coaching, pragmatism suggests a legitimate moral end that could be owned by coaches (Dewey, 1920, 2004: 102):

The end is .... the active process [our emphasis] of transforming the existent situation. Not perfection as a final goal, but the ever-enduring process of perfecting, maturing, refining is the aim in living. Honesty, industry, temperance, justice, like health, wealth and learning, are not goods to be possessed as they would be if they expressed fixed ends to be attained. ... Growth itself is the only moral 'end'.

As an expression of the principle of developmentalism (Bachkirova et al., 2017b), it helps to acknowledge the ultimate value of coaching as growth through "gradual maturing of our capacities as species for adaptation" (Pring, 2014: 137). This does not undermine the self-determination of clients or the importance of their agenda. The client still determines the focus of inquiry by bringing to explore her indeterminate situation that created the initial disequilibrium. The coach, however, looks at this situation as an opportunity not just to solve a particular problem, but also to extend the client's overall capacity to make meaning and address any other situations: "the development of an ever more comprehensive and accommodating organization of experience" (Pring, 2014: 142).

Affirmation of growth as both the means and the end of coaching is not only compatible with various approaches to coaching, but can also be utilized to unite and integrate them (Kegan, 1982; Cook-
Greuter, 1999; Bachkirova, 2011). The goals of these approaches can then be seen as milestones that clients can reach in the process of growth and development, with each variation adding an important capability to be built upon for the next stage of the process.

This captures the influence of evolutionary theory upon pragmatism. Organizational coaches already act as if there is a gradual maturing of capacities as species for adaptation, including the increase of sensory and reflective capacities (Cox et al., 2014b; Athanasopoulou \& Dopson, 2015; Western, 2012). It would be more consistent if they then own development as an ultimate purpose of coaching, which would align them, by default, with a Deweyan pragmatist perspective. This does not need to be expressed in any controversial teleological sense with a predetermined end state, but as a sociobiological drive to learn, which does not stop in adulthood. Psychological development is open-ended with infinite unfolding potential in the same way as any learning process (Dewey, 1916). It happens in response to living in and acting in and on this world. It is influenced by many internal and external factors, and thus, happens at a different pace for different people. As development is a natural process, the amplifiers of this process, such as people and events, are also natural.

\section{Practicing in Diverse Ways: A Pragmatic Epistemological Attitude}

In the previous section, we described two examples of using pragmatist concepts for conceptualizing coaching in organizations in the most generic way, suggesting concepts that we believe can serve as building blocks toward the eventual formulation of the identity of this practice. At the same time, earlier in the article, we acknowledged that coaching practitioners come from different backgrounds and work in many different ways (see Table 1), and the diversity of influences on coaching approaches is still growing. Arguing for the importance of the dialogue between diverse traditions in the development of theoretical knowledge, we suggested that philosophical pragmatism provides a theoretical framework to do just this. However, we also believe that pragmatism has already something useful to offer to coaches and students when they engage in reflexive activities, develop the rationale for their approaches to practice, and construct their role as practitioners. In this section, we provide an example of how a pragmatic epistemological attitude can be used when dealing with specific conceptual clashes of 
values that various perspectives advocate, as well as for coping with the inconsistent messages they generate (Western, 2012). We focus only on one dimension of differences that we believe is intersecting in relation to all others: that which differentiates the "modernist" and the "postmodernist." This attitude can also be useful for dealing with other dimensions of differences and enabling learning from a wider range of other influences on organizational coaching.

That practitioners will be influenced, as anybody will be, by a whole range of historical, cultural, political, psychological, and professional factors when developing their models of practice, is inevitable (Garvey et al., 2014; Western, 2012). Such influences are manifested in conflicting worldviews, or "world hypotheses," as Stephen Pepper called them (1942), such as the ongoing confrontation between "modernism" and "postmodernism," or "positivism" and "constructivism," that are currently present in the professional world and academic discourse. As a consequence of this, practitioners' values and epistemological attitudes, whether acknowledged or not, may become attuned to these worldviews in various proportions and manifested simultaneously. A focused awareness of this phenomenon can reveal that these sets of values are often in conflict when practitioners construct their identity as coaches (Western, 2012; Bachkirova, 2016a).

In Bachkirova's (2016a) analysis of literature and documents created by professional bodies, these contradictory values and corresponding behaviors of coaches are shown in the first two columns of Table 2. Bachkirova suggested seeing the expression of these concurrent influences on the organizational coach as the coexistence of two different subselves in the practitioner's role. Each takes the lead in different periods and situations of the coaching relationship. Bachkirova called these a competent self and a dialogic self (Bachkirova, 2016a), whereby competent self is an expression of modernist values, and dialogic self indicates a tendency toward postmodernist views.

In extending this view and following Fishman's (1999) suggestions that pragmatism is a "third way" in comparison to modernism and postmodernism, we postulate the existence of a pragmatic self in the coach that reflects an appreciation of the main features of pragmatism. As with the other "subselves," the pragmatic self becomes present at those situations where this subself of the coach is called upon. Therefore, the third column (Table 2) describes the way this pragmatic self may be different from the competent and dialogic selves, and how it provides an additional choice for making sense of the role of the coach by integrating the idea of action more explicitly.

For example, the pragmatic self suggests embracing the need for experimentation and action as a diversification in the coach repertoire of roles with a subtle shift from the coach taking responsibility for added value to the coaching process by using her expertise (competent self). It also indicates a shift from rejecting the idea of expertise, and with this,

TABLE 2

Comparison Between Competent, Dialogic, and Pragmatic Selves. (Adapted and extended from Bachkirova, 2016a)

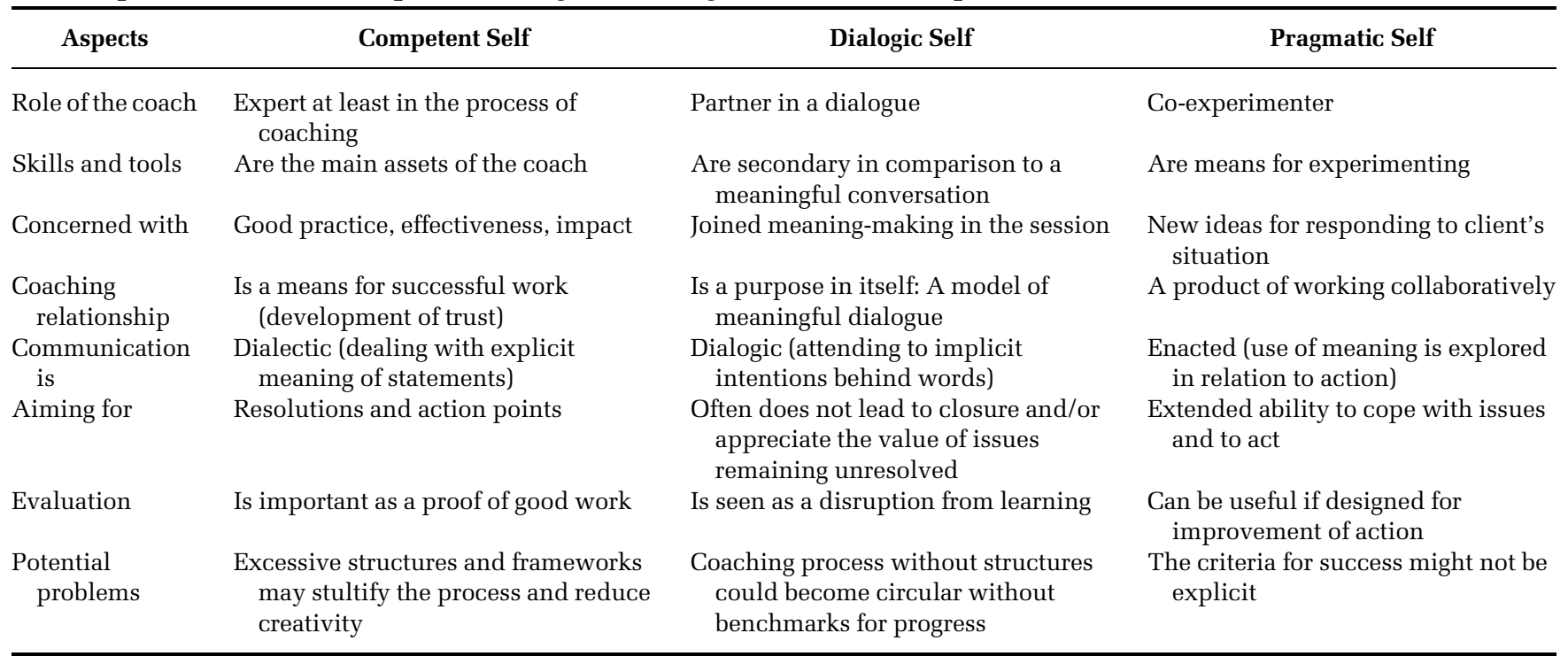


only focusing on the development of the conversation (dialogic self). The differences would also be noticeable in the focus of attention by coaches shifting from good practice and impact on the one hand (competent self) and from only meaningmaking in a conversation on another hand (dialogic self) to the generation of new ideas for the client's actions (pragmatic self).

In addition, we believe that pragmatism can offer even more than an alternative to the competent and dialogic self within this intersecting dimension of differences. The pragmatic epistemological attitude also suggests how the divergent suggestions that follow from each self can be integrated and used when appropriate in different situations. Being pluralistic and inclusive, pragmatism allows "a space for maneuver" and flexibility in beliefs while also providing a coherent approach based on the importance of action. For example, "skills and tools" of the coach that are very important for a competent self, but not important or even distracting for a dialogic self, become a means for experimentation for a pragmatic self. This does not preclude the use of techniques as an important element of practice when a competent self is called upon, but subordinates techniques to a more important purpose. When a dialogic self is engaged, pragmatism offers the use of techniques only when it is justified by the need to bring the conversation to active experimentation. This suggests that there are multiple ways of engaging with the client that are available to the coach, and their value for coaching outcomes is determined by the opportunity for the client to generate new ways to act: an essential aim of the pragmatic self.

In the same way we believe that the adoption of an overarching pragmatic attitude by the coaching practitioner would facilitate sensitivity toward any alternative values and attitudes in addition to the distinctions discussed above. Allowing for the diversity of different traditions and modalities of coaching as a variation of their own subselves may encourage awareness of multiple influences and help coaches recognize the complexity of their practice and to critically evaluate various discourses and traditions without dismissing their benefits. This attitude would also be useful in evaluating the quality and relevance of knowledge presented in academic journals. Coaches and students may be able to recognize how certain values and worldviews shape this knowledge and learn to "recalibrate the message" by recognizing the particular lens of the author. This should encourage appreciation of the strengths of an argument while also engendering caution toward "questionable practices" associated with different traditions in publications (Butler, Delaney, \& Spoelstra, 2017). Similarly, a pragmatic attitude would be very welcome in relation to the controversies and debates concerning the professionalization of coaching and the various activities of the relevant professional bodies (Garvey, 2011; Gray, 2007; Bachkirova \& Lawton Smith, 2015; Athanasopoulou \& Dopson, 2015).

\section{CONCLUSIONS}

We argued that the philosophy of pragmatism (in its "classical formulation") offers a broad and deep conceptual framework that complements contemporary efforts of coaching scholars in furthering the theoretical understanding of coaching in organizations. Our personal preference for pragmatism in the development of coaching as a discipline is also fueled by an awareness of the increasing need in general for constructive dialogue in all areas of life, given the current state of the world. The pragmatic stance seems to be particularly germane in situations where there is a lack of communication and understanding between different groups of people, and where clashes of perspectives occur. With its acknowledgment of the fallibility of knowledge and the partiality of different perspectives, the pragmatic stance encourages keeping dialogue open and greater "interaction with 'otherness"” (Kelemen \& Rumens, 2008: 49).

For establishing the identity of organizational coaching in particular, we have argued that at this stage of the process, recognizing the complexity of practice and acknowledging the multiplicity of coaching approaches is more productive than trying to arrive at definitional clarity or any definitive integration of diverse views. As theoretical understanding of organizational coaching is still a "work in progress," we advocate a pragmatic epistemological attitude that accommodates the use of different methodologies, pragmatic case studies, new ideas to encourage the continuation of dialogue and the keeping of minds open; always the best strategy for developing a new discipline, and not a bad strategy for intellectual inquiry, full stop.

For further theorizing of organizational coaching, we introduced a pragmatist understanding of the role of action as an essential element of the coaching process. Our interpretative analysis served to demonstrate the value of seeing the coaching process as a joint and active inquiry for both educators and coaches. We believe that conceptualizing 
organizational coaching as an end and means for individual development is also a substantial contribution, as it legitimizes coaching as a practice in service of psychological growth on a large scale instead of the misleading simplicity of value-neutral intervention. If followed through, this should establish an ambitious premise for the direction and criteria of progress in organizational coaching assignments, and it needs to be incorporated by educators, practitioners, and policy makers. We hope that coaches who work on their models of practice would see that the pragmatic epistemological attitude offers a unique opportunity for flexibility while also providing a coherent standpoint for understanding their roles.

Finally, we recognize that in trying to paint a picture of such magnitude, it is inevitable that some ideas have only being sketched rather than fully developed. In terms of research, we would love to see rich empirical data supporting or questioning the theoretical position set here. For examples, qualitative investigations could focus on the experience of joint inquiry and what makes it really "joint." The phenomenon of the multiple self of the coach needs to be explored through both self-reflection and consideration of the observers' perspective. However, our main intention here was to stimulate and encourage further conceptual work on organizational coaching. It is our hope, therefore, that the proposed ideas will be picked up by others and taken further, sideways or even in the opposite direction; better still if this is done in the spirit of philosophical pragmatism.

\section{REFERENCES}

Abbott, G., \& Salomaa, R. 2017. Cross-cultural coaching: An emerging practice. In T. Bachkirova \& G. Spence \& D. Drake (Eds.), The SAGE handbook of coaching: 453-469. London: Sage.

Alvesson, M. 2001. Knowledge work: Ambiguity, image and identity. Human Relations, 54(7): 863-886.

Arnaud, G. 2003. A coach or a couch? A Lacanian perspective on executive coaching and consulting. $\mathrm{Hu}$ man Relations, 56(9): 1131-1154.

Athanasopoulou, A., \& Dopson, S. 2015. Developing leaders by executive coaching: Practice and evidence. Oxford, UK: Oxford University Press.

Avolio, B., \& Hannah, S. 2008. Developmental readiness: Accelerating leader development. Consulting Psychology Journal, 60: 331-347.

Bachkirova, T. 2011. Developmental coaching: Working with the self. Maidenhead, UK: Open University Press.
Bachkirova, T. 2015. Self-deception in coaches: An issue in principle and a challenge for supervision. Coaching: An International Journal of Theory, Research and Practice, 8(1): 4-19.

Bachkirova, T. 2016a. The self of the coach: Conceptualization, issues, and opportunities for practitioner development. Consulting Psychology Journal, 68(2): 143-156.

Bachkirova, T. 2016b. A new perspective on self-deception for applied purposes. New Ideas in Psychology, 43: 1-9.

Bachkirova, T. 2017. Developing a knowledge base of coaching: Questions to explore. In T. Bachkirova, G. Spence, \& D. Drake (Eds.), The SAGE handbook of coaching: 23-41. London: Sage.

Bachkirova, T., \& Kauffman, C. 2009. The blind men and the elephant: Using criteria of universality and uniqueness in evaluating our attempts to define coaching. Coaching: An International Journal of Theory, Research and Practice, 2(2): 95-105.

Bachkirova, T., \& Lawton Smith, C. 2015. From competencies to capabilities in the assessment and accreditation of coaches. International Journal of Evidence Based Coaching and Mentoring, 13(2): 123-140.

Bachkirova, T., Spence, G., \& Drake, D. 2017a. Introduction. In T. Bachkirova \& G. Spence \& D. Drake (Eds.), The SAGE handbook of coaching: 1-22. London: Sage.

Bachkirova, T., Jackson, P., Gannon, J., Iordanou, I., \& Myers, A. 2017b. Re-conceptualizing coach education from the perspectives of pragmatism and constructivism. Philosophy of Coaching: An International Journal, 2(2): 29-50.

Baker, S. 2015. Practitioners' perceptions of the boundaries between coaching and counselling. Unpublished $\mathrm{PhD}$ Thesis. University of Bedfordshire.

Baron, L., \& Morin, L. 2009. The coach-coachee relationship in executive coaching: A field study. Human Resource Development Quarterly, 20: 85-106.

Bates, R., \& Chen, H. 2004. Human resource development value orientations. Human Resource Development International, 7(3): 351-371.

Becher, T. 1994. The significance of disciplinary differences. Studies in Higher Education, 19(2): 151-161.

Bem, S., \& de Jong, H. 2013. Theoretical issues in psychology: An introduction, (3rd ed.). London: Sage.

Bennett, J., \& Campone, F. 2017. Coaching and theories of learning. In T. Bachkirova \& G. Spence \& D. Drake (Eds.), The SAGE handbook of coaching: 102-138. London: Sage.

Berger, J. 2012. Learning on the job: Developing leaders for a complex world. Stanford, CA: Stanford University Press. 
Berglas, S. 2002. The dangers of executive coaching. Harvard Business Review, 80(6): 86-92.

Bernstein, R. 1983. Beyond objectivism and relativism. Oxford, UK: Blackwell.

Bluckert, P. 2014. The Gestalt pproach to coaching. In E. Cox, T. Bachkirova, \& D. Clutterbuck (Eds.), The Complete handbook of coaching (2nd ed.): 77-90. London: Sage.

Bond, A., \& Naughton, N. 2011. The role of coaching in managing leadership transitions. International Coaching Psychology Review, 6(2): 165-180.

Boyatzis, R., Smith, M., \& Van Oosten, E. 2015. Illuminating the scholarship of coaching. The Journal of Applied Behavioral Science, 51(2): 149-151.

Bozer, G., \& Jones, R. 2018. Understanding the factors that determine workplace coaching effectiveness: A systematic literature review. European Journal of Work and Organizational Psychology, 10.1080/1359432X.2018.1446946.

Brug, J., Conner, M., Harré, N., Kremers, S., McKellar, S., \& Whitelaw, S. 2005. The Transtheoretical Model and stages of change: A critique: Observations by five commentators on the paper by Adams, J. and White, M. (2004). Why don't stage-based activity promotion intervention work? Health Education Research, 20(2): 244-258.

Buchler, J. 1955. Introduction. Philosophical writings of Peirce: vii-xvi. New York: Dover.

Burke, F. T. 2013. What pragmatism was. Bloomington: Indiana University Press.

Butler, N., Delaney, H., \& Spoelstra, S. 2017. The grey zone: Questionable research practices in the business school. Academy of Management Learning $\&$ Education, 16(1): 94-109.

Campbell, J. 1995. Understanding John Dewey: Nature and cooperative intelligence. Chicago and LaSalle. IL: Open Court.

Cavanagh, M. 2009. Coaching as a method for joining up the dots: An interview by T. Bachkirova and C. Kauffman. Coaching: An International Journal of Theory, Research and Practice, 2(2): 106-116.

Cavanagh, M., \& Lane, D. 2012. Coaching psychology coming of age: The challenges we face in the messy world of complexity. International Coaching Psychology Review, 7(1): 75-90.

Cavanagh, M., \& Grant, A. 2014. The solution-focused approach to coaching. In E. Cox, T. Bachkirova, \& D. Clutterbuck (Eds.), The complete handbook of coaching (2nd ed.): 51-64. London: Sage.

Clutterbuck, D., \& Spence, G. 2017. Working with goals in coaching. In T. Bachkirova, G. Spence, \& D. Drake (Eds.), The SAGE handbook of coaching: 218-237. London: Sage.
CIPD (The Chartered Institute of Personnel Development) 2015. Learning and Development Report 2015. Retrieved from: https://www.cipd.co.uk/knowledge/ strategy/development/surveys.

Cocivera, S., \& Cronshaw, S. 2004. Action frame theory as a practical framework for executive coaching process. Consulting Psychology Journal, 56(4): 234-245.

Cook-Greuter, S. 1999. Postautonomous ego development: Its nature and measurement. Unpublished doctoral thesis. Cambridge, MA: Harvard Graduate School of Education.

Cox, E. 2013. Coaching understood: A pragmatic inquiry into the coaching process. London: Sage.

Cox, E., Bachkirova, T., \& Clutterbuck, D. 2014a. Theoretical traditions and coaching genres: Mapping the territory. Advances in Developing Human Resources, 16(2): 127-138.

Cox, E., Bachkirova, T., \& Clutterbuck, D. 2014b. The complete handbook of coaching. London: Sage.

Cox, E., \& Jackson, P. 2014. Developmental coaching. In E. Cox, T. Bachkirova, \& D. Clutterbuck (Eds.), The complete handbook of coaching (2nd ed.): 215-227. London: Sage.

Day, D. 2001. Leadership development: A review in context. The Leadership Quarterly, 11(4): 581-613.

Deci, E., \& Ryan, R. 2000. The 'what' and 'why' of goal pursuits: Human needs and the self-determination of behavior. Psychological Inquiry, 11(4): 227-268.

de Haan, E., Bertie, C., Day, A., \& Sills, C. 2010. Clients' critical moments of coaching: Toward a "client model" of executive coaching. Academy of Management Learning \& Education, 9(4): 607-621.

de Haan, E., \& Duckworth, A. 2013. Signaling a new trend in executive coaching outcome research. International Coaching Psychology Review, 8(1): 6-19.

de Haan, E., \& Gannon, J. 2017. The coaching relationship. In T. Bachkirova, G. Spence, \& D. Drake (Eds.), The SAGE handbook of coaching: 195-217. London: Sage.

Dewey, J. 1916. Democracy and education: An introduction to the philosophy of education. London: Macmillan.

Dewey, J. 1920, 2004. Reconstruction in philosophy. New York: Dover.

Dewey, J. 1925. Experience and nature. London: George Allen and Unwin.

Dewy, J. 1929, 1980. The quest for certainty. New York: Perigee.

Dewey, J. 1938. Logic: The theory of inquiry. New York: Henry Holt \& Company. 
Drake, D. 2017. Working with narrative in coaching. In T. Bachkirova, G. Spence, \& D. Drake (Eds.), The SAGE handbook of coaching: 291-309. London: Sage.

Ellinger, A. D., Hamlin, R. G., \& Beattie, R. S. 2008. Behavioural indicators of ineffective managerial coaching: A cross national study. Journal of European Industrial Training, 32(4): 240302.

Ellinger, A., Beattie, R., \& Hamlin, R. 2014. The manager as a coach. In E. Cox, T. Bachkirova, \& D. Clutterbuck (Eds.), The complete handbook of coaching (2nd ed.): 256-270. London: Sage.

Ellinger, A., Hamlin, R., \& Beattie, R. 2017. Coaching in the HRD context. In T. Bachkirova, G. Spence, \& D. Drake (Eds.), The SAGE handbook of coaching: 470-485. London: Sage.

Fendler, L. 2003. Teacher reflection in a hall of mirrors: Historical influences and political reverberations. Educational Researcher, 32(3): 16-25.

Fillery-Travis, A., \& Lane, D. 2006. Does coaching work or are we asking the wrong question? International Coaching Psychology Review, 1(1): 23-36.

Fillery-Travis, A., \& Collins, R. 2017. Discipline, profession and industry: How our choices shape our future. In T. Bachkirova, G. Spence, \& D. Drake (Eds.), The SAGE handbook of coaching: 729-744. London: Sage.

Fishman, D. 1999. The case for pragmatic psychology. New York: New York University Press.

Filsinger-Mohun, C. 2011. How can maternity coaching influence women's re-engagement with their career development: A case study of private law firms? Unpublished dissertation. Oxford, UK: Oxford Brookes University.

Francis, S., \& Zarecky, A. 2017. Working with strengths in coaching. In T. Bachkirova, G. Spence, \& D. Drake (Eds.), The SAGE handbook of coaching: 363-380. London: Sage.

Garvey, B. 2011. A very short, fairly interesting and reasonably cheap book about coaching and mentoring. London: Sage.

Garvey, B. 2017. Issues of assessment and accreditation of coaching. In T. Bachkirova, G. Spence, \& D. Drake (Eds.), The SAGE handbook of coaching: 680-695. London: Sage.

Garvey, B., Stokes, P., \& Megginson, D. 2014. Coaching and mentoring: Theory and practice (2nd ed.). London: Sage.

Gessnitzer, S., \& Kauffeld, S. 2015. The working alliance in coaching: Why behavior is the key to success. The Journal of Applied Behavioral Science, 51(2): 177197.
Grant, A. 2006. A personal perspective on professional coaching and development of coaching psychology. International Coaching Psychology Review, 1(1): 12-22.

Grant, A. 2011. Workplace, executive and life coaching: An annotated bibliography from the behavioural science and business literature. Sydney, AUS: Coaching Psychology Unit, University of Sydney. Retrieved from: http://www.instituteofcoaching.org/images/pdfs/ CoachingResearchStudiesList.pdf.

Grant, A. 2013. The efficacy of coaching. In J. Passmore, D. Peterson, \& T. Freire (Eds.), The Wiley-Blackwell handbook of the psychology of coaching and mentoring: 15-39. Chichester, UK: Wiley-Blackwell.

Grant, A. 2014. Autonomy support, relationship satisfaction and goal focus in the coach-coachee relationship: Which best predict coaching success? Coaching: An International Journal of Theory, Research and Practice, 7(1): 18-38.

Grant, A., Passmore, J., Cavanagh, M., \& Parker, H. 2010. The state of play in coaching today: A comprehensive review of the field. In G. Hodgkinson \& K. Ford (Eds.), International review of industrial and organizational psychology 2010: 125-167. New York: WileyBlackwell.

Gray, D. 2007. Facilitating management learning: Developing critical reflection through reflective tools. Management Learning, 38: 495-517.

Gray, D., Garvey, B., \& Lane, D. 2016. A critical introduction to coaching and mentoring: Debates, dialogues and discourses. London: Sage.

Haack, S. 2006. Introduction. In S. Haack \& R. Lane (Eds.), Pragmatism, old and new: 15-67. New York: Prometheus Books.

Hawkins, P., \& Smith, N. 2013. Coaching, mentoring and organizational consultancy: Supervision, skills and development (2nd ed.), Maidenhead, UK: Open University Press.

Hildebrand, D. 2003. Beyond realism and anti-realism. Nashville, TN: Vanderbilt University Press.

Hildebrand, D. 2013. Dewey's pragmatism: Instrumentalism and meliorism. In A. Malachowski (Ed.), The Cambridge companion to pragmatism: $55-82$. Cambridge, UK: Cambridge University Press.

Hogan, B. 2009. Towards a truly pragmatic philosophy of social science. Human Studies, 32: 383-389.

Hunt, J., \& Weintraub, J. 2004. Learning developmental coaching. Journal of Management Education, 28(1): 39-61.

ICF (International Coach Federation) 2016. Annual Report. Retrieved from: https://www.coachfederation.org/ newsdetail.cfm?ItemNumber $=4463$. 
Iordanou, I., Hawley, R., \& Iordanou, C. 2017. Values and ethics in coaching. London: Sage.

Jackson, P. 2004. Does it matter what the coach thinks? A new foundation for professional development. In D. Drake, \& D. Brennan \& K. Kortz (Eds.), The philosophy and practice of coaching: Insights and issues for a new era: 73-90. Chichester, UK: John Wiley and Sons.

James, W. 1907, 1982. An interview: Pragmatism - What is it? In H. S. Thayer, (Ed.), Pragmatism: The classic writings: 130-134. Indianapolis, IN: Hackett.

James, W. 1904, 2000. A world of pure experience. In G. Gunn (Ed.), William James: Pragmatism and other writings: 314-326. London: Penguin.

Jenkins, S. 2016. Beyond 'crude pragmatism' in sports coaching: Insights from C.S. Peirce, William James, and John Dewey. International Journal of Sports Science \& Coaching, 12(1): 8-19.

Jones, R., \& Corner, J. 2012. Seeing the forest and the trees: A complex adaptive systems lens for mentoring. $\mathrm{Hu}-$ man Relations, 65(3): 391-411.

Joseph, S. 2014. The person-centered approach to coaching. In E. Cox, T. Bachkirova, D. Clutterbuck (Eds.), The complete handbook of coaching (2nd ed.): 65-76. London: Sage.

Joseph, S., \& Bryant-Jefferies, R. 2007. Person-centered coaching psychology. In S. Palmer \& A. Whybrow (Eds.), Handbook of coaching psychology: 211-228. London, UK: Routledge.

Kavanagh, F. 2015. Models for job support and coaching for people with disabilities in the European Union. Final Report. Retrieved from: https://www.slideshare.net/ undpukraine/job-support-and-coaching-for-people-withdisabilities-in-the-eu.

Kegan, R. 1982. The evolving self: Problem and process in human development. Cambridge, MA: Harvard University Press.

Kelemen, M., \& Rumens, N. 2008. An introduction to critical management research. London: Sage.

Kempster, S., \& Iszatt-White, M. 2012. Towards coconstructed coaching: Exploring the integration of coaching and co-constructed autoethnography in leadership development. Management Learning, 44(4): 319-336.

Kenworthy, A. L., Passarelli, A., \& Van Oosten, E. 2014. Introduction: Coaching and positive emotions: Exploring a collection of resources in the health and wellness domain. Academy of Management Learning \& Education, 13(2): 290-292.

Kilpinen, E. 2009. Pragmatism as a philosophy of action. In S. Pihlstrom \& H. Rydenfelt (Eds.), Pragmatist perspectives: 163-179. Helsinki: Philosophical Society of Finland.
Knowles, M. 1978. The adult learner: A neglected species. Houston, TX: Gulf.

Knowles, M. S., Holton, E. F., \& Swanson, R. A. 2015. The adult learner. New York: Routledge.

Kolb, D. 1984, 2014. Experiential learning: Experience as the source of learning and development. Englewood Cliffs, NJ: Prentice Hall.

Korotov, K. 2017. Coaching for leadership development. In T. Bachkirova, G. Spence, \& D. Drake (Eds.), The SAGE handbook of coaching: 139-158. London: Sage.

K. Korotov, E. Florent-Treacy, M. Kets de Vries, \& A. Bernhardt (Eds.) 2012. Tricky coaching: Difficult cases in leadership coaching. Basingstoke, UK: Palgrave Macmillan.

Lane, D. 2017. Trends in development of coaches (education and training): Is it valid, is it rigorous and is it relevant? In T. Bachkirova, G. Spence, \& D. Drake (Eds.), The SAGE handbook of coaching: 647-661. London: Sage.

Lawton-Smith, C. 2017. Coaching for resilience and wellbeing. In T. Bachkirova, G. Spence, \& D. Drake (Eds.), The SAGE handbook of coaching: 346-380. London: Sage.

MacKie, D. 2015. The effects of coachee readiness and core self-evaluations on leadership coaching outcomes: A controlled trial. Coaching: An International Journal of Theory, Research and Practice, 8(2): 120-136.

Martela, F. 2015a. Fallible inquiry with ethical end-in-view: A pragmatist philosophy of science for organizational research. Organization Studies, 36(4): 537-563.

Martela, F. 2015b. Pragmatism as an attitude. In U. Zackariasson (Ed.), Action, belief and inquiry Pragmatist perspectives on science, society and religion: 187-207. Nordic Studies in Pragmatism 3. Helsinki: Nordic Pragmatism Network.

Menand, L. 2001. The metaphysical club. London: Flamingo.

Mezirow, J. 1990. Fostering critical reflection in adulthood: A guide to transformative and emancipatory learning. San Francisco, CA: Jossey-Bass.

Mitchell, S. 2009. Unsimple truths. Chicago: University of Chicago Press.

Myers, A. 2017. Researching the coaching process. In T. Bachkirova, G. Spence, \& D. Drake (Eds.), The SAGE handbook of coaching: 589-609. London: Sage.

Palmer, S., \& Whybrow, A. (Eds.) 2007. Handbook of coaching psychology. London: Routledge.

Peirce, C. S. 1878, 1955a. How to make our ideas clear. In J. Buchler (Ed.), Philosophical writings of Peirce: 23-42. New York: Dover. 
Peirce, C. S. 1878, 1955b. Fixation of belief. In J. Buchler (Ed.), Philosophical writings of Peirce: 5-22. New York: Dover.

Peltier, B. 2001. The psychology of executive coaching. Hove: Brunner-Routledge.

Pepper, S. 1942. World hypotheses: A study in evidence. Berkeley, Los Angeles: University of California Press.

Peterson, D. 1991. Connection and disconnection of research and practice in the education of professional psychologists. The American Psychologist, 46: 422-429.

Pihlstrom, S. 2015. Introduction. In S. Pihlstrom (Ed.), The Bloomsbury companion to pragmatism: 3-36. London: Sage.

Pring, R. 2014. John Dewey. London: Bloomsbury.

Putnam, R. 2002. Taking pragmatism seriously. In J. Conant \& U. Zeglen (Eds.), Hilary Putnam: Pragmatism \& realism: 7-11. Abingdon, UK: Routledge.

Putnam, R. 2017. Democracy as a way of life. In D. Macarthur (Ed.), Pragmatism as a way of Life: The lasting legacy of William James and John Dewey: 439-452. Cambridge: Belknap Harvard.

Reissner, S., \& Du Toit, A. 2011. Power and the tale: Coaching as storytelling. Journal of Management Development, 30(3): 247-259.

Report, Ridler. 2013. Trends in the use of executive coaching. London: Ridler \& Co.

Rockmore, T. 2002. The epistemological promise of pragmatism. In M. Aboulafia, \& M. Brookman, \& C. Kemp (Eds.), Habermas and pragmatism: 47-64. London: Routledge.

Rodgers, C. 2002. Defining reflection: Another look at John Dewey and reflective thinking. Teachers College Record, 104(4): 842-866.

Rogers, J. 2012. Coaching skills: A handbook (3rd ed.), Maidenhead, UK: Open University Press.

Rorty, R. 1980a. Philosophy and the mirror of nature. Oxford, UK: Blackwell.

Rorty, R. 1980b. Pragmatism, relativism, and irrationalism. Proceedings and Addresses of the American Philosophical Association, 56(6): 717-738.

Rosenbaum, P. 2015. Making our ideas clear: Pragmatism in psychoanalysis. Charlotte, NC: IAP, Inc.

Rumens, N., \& Kelemen, M. 2016. American pragmatism and organization studies: Concepts, themes and possibilities. In M. Kelemen \& N. Rumens (Eds.), American pragmatism and organizations: $3-24$. New York: Gower Publishing.

Salomaa, R. 2015. Expatriate coaching: Factors impacting coaching success. Journal of Global Mobility, 3(3): 216-243.
Segers, J., Vloeberghs, D., Henderickx, E., \& Inceoblu, I. 2011. Structuring and understanding the coaching industry: The coaching cube. Academy of Management Learning \& Education, 10(2): 204-221.

Serenko, A., \& Bontis, N. 2013. The intellectual core and impact of the knowledge management academic discipline. Journal of Knowledge Management, 17(1): 137-155.

Schön, D. 1987. Educating the reflective practitioner: Toward a new design for teaching and learning in the professions. New York: Basic Books.

Shoukry, H. 2014. Coaching for emancipation: A framework for coaching in oppressive environments. Unpublished PhD thesis, Oxford: Oxford Brookes University.

Shoukry, H. 2017. Coaching for social change. In T. Bachkirova, G. Spence, \& D. Drake (Eds.), The SAGE handbook of coaching: 176-194. London: Sage.

Spence, G., \& Deci, E. 2013. Self-determination with coaching contexts: Supporting motives and goals that promote optimal functioning and well-being. In S. David, D. Clutterbuck, \& D. Megginson (Eds.), Beyond goals: Effective strategies for coaching and mentoring: 85-108. Padstow: Gower.

Spinelli, E. 2014. Existential coaching. In E. Cox, T. Bachkirova, \& D. Clutterbuck (Eds.), The complete handbook of coaching (2nd ed.): 91-103. London: Sage.

Stacey, R. D. 2003. Strategic management and organizational dynamics: The challenge of complexity. Harlow: Prentice-Hall.

Stacey, R. D. 2012. Comment on debate article: Coaching Psychology Coming of Age: The challenges we face in the messy world of complexity. International Coaching Psychology Review, 7(1): 91-95.

Stern, L., \& Stout-Rostron, S. 2013. What progress has been made in coaching research in relation to 16 ICRF focus areas from 2008 to 2012? Coaching: An International Journal of Theory, Research and Practice, 6(1): 7296.

Strozzi-Heckler, R. 2014. The art of somatic coaching. Berkley, CA: North Atlantic Books.

Talisse, R., \& Aikin, S. 2008. Pragmatism: A guide for the perplexed. London: Continuum.

Thayer-Bacon, B. J. 2015. Education. In S. Pihlstrom (Ed.), The Bloomsbury companion to pragmatism: 188202. London: Bloomsbury.

Theeboom, T., Beersma, B., \& van Vianen, A. 2013. Does coaching work? A meta-analysis on the effects of coaching on individual level outcomes in an organizational context. The Journal of Positive Psychology, 9(1): 1-18. 
Tschannen-Moran, B. 2014. Skills and performance coaching. In E. Cox, T. Bachkirova, \& D. Clutterbuck (Eds.), The complete handbook of coaching (2nd ed.): 201-214. London: Sage.

van Nieuwerburgh, C. 2014. An introduction to coaching skills: A practical guide. London: Sage.

Wacker, J. 1998. A definition of theory: Research guidelines for different theory building research methods in operations managements. Journal of Operations Management, 16: 361-385.

Wasylyshyn, K. 2004. Coaching the superkeepers. In L. Berger \& D. Berger (Eds.), The talent management handbook: 320-336. London: McGraw-Hill.

Weick, C. W. 2008. Issues of consequences: Lessons for educating tomorrow's business leaders from philosopher William James. Academy of Management Learning $\mathcal{E}$ Education, 7(1): 88-98.

Welman, P., \& Bachkirova, T. 2010. Issues of power in coaching relationship. In S. Palmer \& A. McDowell (Eds.), The coaching relationship: 139-158. London: Routledge.

Western, S. 2012. Coaching and mentoring: A critical text. London: Sage.

Whitmore, J. 2008. The evolution of coaching: An interview by C. Kauffman \& T. Bachkirova. Coaching:
An International Journal of Theory, Research and Practice, 1(1): 11-15.

Whittington, J. 2016. Systemic coaching and constellations, (2nd ed.). London: Kogan Page.

Wilson, C. 2007. Best practice in performance coaching: A handbook for leaders, coaches, HR professionals and organizations. London: Kogan Page.

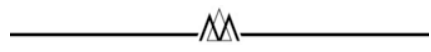

Tatiana Bachkirova is a professor of coaching psychology and Director of the International Centre for Coaching and Mentoring Studies at Oxford Brookes University, UK. She received her $\mathrm{PhD}$ in organizational psychology from St. Petersburg University in Russia. Her research interests are in developmental coaching, coaching supervision, and philosophy of coaching.

Simon Borrington is an honorary research associate with the International Centre for Coaching and Mentoring Studies at Oxford Brookes University, UK. His research interests are in the philosophy of psychology, the role of pragmatism in understanding human experience, and the interface between emotion and cognition. 
Copyright of Academy of Management Learning \& Education is the property of Academy of Management and its content may not be copied or emailed to multiple sites or posted to a

listserv without the copyright holder's express written permission. However, users may print, download, or email articles for individual use. 